\title{
POLSKA RZECZPOSPOLITA LUDOWA WOBEC KONFLIKTU W BIAFRZE 1967-1970
}

Streszczenie. Artykuł analizuje politykę Polski wobec konfliktu w Biafrze w latach 19671970. Podstawę badań stanowią niepublikowane materiały zgromadzone w Archiwum Ministerstwa Sprawa Zagranicznych. Zdaniem autora polska dyplomacja zachowując zdystansowane stanowisko wobec secesji Regionu Wschodniego Nigerii i popierając rząd federalny kierowała się chęcią podtrzymania dobrych relacji politycznych i gospodarczych. Zrównoważona polityka pozwoliła wziąć udział w Międzynarodowej Grupie Obserwatorów, co przyczyniło się do wzrostu prestiżu państwa na arenie międzynarodowej.

Słowa kluczowe: Biafra, Nigeria, polityka zagraniczna Polski, Polska Rzeczypospolita Ludowa, wojna domowa.

\section{Wstęp}

K onflikt wewnętrzny w Nigerii w latach 1967-1970 stanowił klasyczny przykład kryzysu w młodym państwie afrykańskim, którego ustalone przez kolonizatorów granice, nie odzwierciedlały uwarunkowań etnicznych i religijnych. Z punktu widzenia analizy stosunków międzynarodowych w okresie zimnej wojny wymyka się on klasycznemu schematowi międzyblokowej rywalizacji, ponieważ rząd centralny był oficjalnie popierany zarówno przez państwa Zachodu - Stany Zjednoczone i Wielką Brytanię, jak również przez państwa obozu socjalistycznego, zaś separatystów wspierały m.in. Francja, Hiszpania i Portugalia dążące do zabezpieczenia swych interesów gospodarczych związanych z eksploatacją nigeryjskich złóż naturalnych.

Celem artykułu jest prezentacja polityki Polskiej Rzeczypospolitej Ludowej wobec konfliktu rządu centralnego w Nigerii z secesjonistyczną prowincją Biafry w latach 1967-1970. Nigeria była jednym z najważniejszych partnerów Polski w Afryce Subsaharyjskiej, dlatego też rząd w Warszawie wspierał walkę władz federalnych o zachowanie jedności państwa. 
W artykule bazując na niepublikowanych materiałach z Archiwum Ministerstwa Spraw Zagranicznych zaprezentowano metody i środki polskiej polityki zagranicznej zastosowane wobec stron konfliktu, a także formy aktywności polskiej dyplomacji stosowane na arenie międzynarodowej. Za główne środki należy uznać poparcie polityczne, a także udział Polaków w Międzynarodowej Grupie Obserwatorów.

Dyplomacja polska starała się realizować w Nigerii głównie założenia polityki zagranicznej w dziedzinie politycznej i gospodarczej. W sferze politycznej dążono do uzyskania poparcia dla inicjatyw rozbrojeniowych czy uznania za ostateczną granicy zachodniej na Odrze i Nysie Łużyckiej. W zakresie stosunków gospodarczych działano na rzecz uzyskania zrównoważonego bilansu handlowego oraz nawiązania długotrwałej kooperacji w zakresie żeglugi i świadczenia pracy przez polskich ekspertów. Należy podkreślić, że cele te wpisywały się w blokową politykę państw socjalistycznych wobec Afryki.

Temat stosunków polsko-nigeryjskich, w porównaniu z relacjami bilateralnymi z innymi państwami afrykańskimi, był przedmiotem badań wielu naukowców. Dotychczas robili to m.in. Mieczysław Cielecki ${ }^{1}$, Jacek Knopek $^{2}$, czy Jacek Machowski ${ }^{3}$. Pułkownik Alfons Olkiewicz prezentował swe refleksje związane z udziałem w Międzynarodowej Grupie Obserwatorów ${ }^{4}$. Niniejszy artykuł po raz pierwszy dokonuje całościowej analizy opracowań i dokumentów archiwalnych dotyczących polityki Polski wobec konfliktu biafrańskiego.

\section{Geneza i przebieg konfliktu w Biafrze}

Jako samodzielny podmiot prawa międzynarodowego Nigeria zaczęła swój byt 1 października 1960 r. Uzyskanie niepodległości od Wielkiej Brytanii poprzedzone było długotrwałymi negocjacjami i przygotowaniem struktury przyszłego państwa. Pokojowy charakter drogi do wolności dawał nadzieję na stabilizację i rozwój gospodarczy. Jednakże zasada uti possidetis ${ }^{5}$ przyjęta za podstawę wyznaczania granic państw postkolonialnych odegrała w przypadku Nigerii rolę czynnika rodzącego konflikty pomiędzy muzułmańskimi

${ }^{1}$ M. Cielecki, Stosunki polsko-nigeryjskie, [w:] Polacy w Nigerii, red. J. Machowski, Z. Łazowski, W. Kozak, Warszawa 1997, s. 44-52.

2 J. Knopek, Stosunki polsko-zachodnioafrykańskie, Toruń 2013.

${ }^{3}$ J. Machowski, Po obu stronach frontu, [w:] Polacy w Nigerii..., s. 68-77.

${ }^{4}$ A. Olkiewicz, Oficerowie polscy w Międzynarodowej Grupie Obserwatorów, [w:] Polacy w Nigerii..., s. 60-68.

5 T. Srogosz, Charakter prawny uti possidetis w prawie międzynarodowym, „Państwo i Prawo” 2011, nr 6, s. 64-76. 
ludami Hausa i Fulani z północy oraz animistami Joruba i chrześcijanami Ibo z południa. Nigeria, jako kolonia brytyjska, od 1947 r. podzielona była na trzy regiony - Północny, Zachodni i Południowy - poddane władzy gubernatora.

Po uzyskaniu niepodległości podział administracyjny nie uległ zmianie, co więcej został utrwalony przez zapisaną w konstytucji zasadę federalizmu. W 1964 r. utworzono czwarty Region Środkowo-Zachodni. Antagonizmy między północą i południem wynikały nie tylko z różnic etnicznych i religijnych, ale także $\mathrm{z}$ asymetrii rozwoju gospodarczego. Prowincje południowe zamieszkane przez mniejszość ludności generowały największą część PKB nowego państwa równocześnie nie poczuwając się do gospodarczej solidarności z regionami północnymi 6 .

Utrzymujące się partykularyzmy doprowadziły na początku 1966 r. do nieudanej próby wojskowego zamachu stanu. Wprawdzie wywodzący się z kręgu młodych oficerów spiskowcy zostali pokonani przez siły rządowe, to władze federalne postanowiły powierzyć stanowisko premiera gen. Aguiyi Ironsi'emu, który, mając na celu likwidację różnic społecznych, zniósł federacyjną strukturę państwa. Takie posunięcie nie doprowadziło do stabilizacji sytuacji w kraju. Wobec licznych strajków i wzrastającego niezadowolenia społecznego 29 lipca armia znowu wypowiedziała posłuszeństwo rządowi. Na skutek udanego przewrotu przywódcą Nigerii został ppłk Yakub Gowon?. Przywrócił on strukturę federacyjną, równocześnie stanowczo sprzeciwiając się dyskusji o przekształceniu Nigerii w konfederację.

Tymczasem w Regionie Wschodnim władzę sprawował mianowany przez gen. Ironsi'ego ppłk Odumegwu Ojukwu, który nie uznał nowych władz w Lagos. Wobec ekonomicznej blokady, 30 maja 1967 r., prowincja ogłosiła niepodległość jako Republika Biafry ${ }^{8}$. Nowy podmiot uzyskał uznanie czterech państw afrykańskich - Tanzanii, Gabonu, Zambii i Wybrzeża Kości Słoniowej ${ }^{9}$. Działania zbrojne przeciwko secesjonistom wojska federalne rozpoczęły 5 lipca 1967 r. Początkowo przewagę w konflikcie uzyskały, wspierane przez instruktorów zagranicznych, siły nieuznawanej republiki ${ }^{10}$. Po przeprowadzeniu pełnej mobilizacji siłom rządowym udało się przełamać front i kontynuować ofensywę, która wiosną 1968 r. doprowadziła do odcięcia secesjonistów od morza, tym samym likwidując możliwość eksportu

${ }^{6}$ J. Kukułka, Historia współczesnych stosunków międzynarodowych 1945-1994, Warszawa 1994, s. 177.

7 P. Calvocoressi, Polityka międzynarodowa po 1945 roku, Warszawa 2010, s. 619.

8 M. Leśniewski, Biafra 1966-1970, [w:] Konflikty kolonialne i postkolonialne w Afryce i Azji 1869-2006, red. P. Ostaszewski, Warszawa 2007, s. 452.

${ }^{9}$ J. Milewski, Polityka zagraniczna Nigerii 1960-1970, Warszawa 1972, s. 64.

${ }_{10}$ M. Sobczyński, Zmiany granic w Afryce w okresie postkolonialnym, „Studia z Geografii Politycznej i Historycznej" 2015, t. 4, s. 79. 
ropy naftowej i pozyskiwania zaopatrzenia z krajów trzecich. Równocześnie przy mediacji Wielkiej Brytanii prowadzono rozmowy pokojowe, które jednak nie doprowadziły do zakończenia konfliktu. Kolejne kampanie sił rządowych skutkowały rozbiciem wojsk samozwańczego podmiotu. 11 stycznia 1970 r. przywódca Biafry ppłk Ojukwu udał się na emigrację, zaś cztery dni później siły biafrańskie ogłosiły bezwarunkową kapitulację ${ }^{11}$.

\section{Stosunki polsko-nigeryjskie w przededniu konfliktu}

Po II wojnie światowej Polska popierała dążenia niepodległościowe ludów znajdujących się pod panowaniem kolonialnym sprzeciwiając się brutalności władz także na obszarze wchodzącym w skład późniejszej Nigerii ${ }^{12}$. W związku z proklamowaniem niepodległości Nigerii premier Józef Cyrankiewicz przesłał na ręce premiera Alhaji Abubakara Tafawa Balewy depeszę gratulacyjną. W listopadzie 1961 r. oba państwa podpisały umowę handlową ${ }^{13}$. Stosunki dyplomatyczne na szczeblu ambasad Polska Rzeczpospolita Ludowa i Federacyjna Republika Nigerii nawiązały 30 maja 1962 r. $^{14}$ Polska placówka została otwarta w Lagos w 1963 r., zaś do 1969 r. interesy nigeryjskie w Polsce reprezentowała jednostka z siedzibą w Moskwie. W okresie będącym przedmiotem badań stanowisko szefa polskiej placówki zajmowali: ambasador Bronisław Musielak (kwiecień 1963 - kwiecień 1967 r.), charge d'affaires ad interim Andrzej Wójtowicz (kwiecień - lipiec 1967 r.) oraz ambasador Mieczysław Dedo (od lipca 1967 r.) $)^{15}$.

W styczniu 1965 r. Ambasada PRL w Lagos oceniała dotychczasowe stosunki bilateralne jako słabo rozwinięte z powodu krótkiego czasu wzajemnej współpracy oraz realizowanych przez Nigerię założeń polityki zagranicznej opierających się na budowie silnych relacji z państwami zachodnimi. Zbieżność poglądów w sprawach istotnych dla ówczesnych stosunków międzynarodowych takich jak np. kwestie rozbrojenia, kolonializmu czy problemów rozwojowych nie wynikała z pogłębionej wymiany poglądów stron, a z przypadkowej zbieżności. Polskę postrzegano w miejscowych kręgach rządowych jako rozwiniętą gospodarkę, dającą perspektywy na podjęcie korzystnej dla młodego państwa kooperacji. Polska dyplomacja w realizacji krajowych interesów gospodarczych wspierała dążenia afrykańskiego partnera do osłabienia więzi neokolonialnych, co pozwoliłoby na zaistnienie na

${ }^{11}$ J. Kukułka, op. cit., s. 178.

12 M. Cielecki, op. cit., s. 44-45.

${ }_{13}$ Stosunki dyplomatyczne Polski 1944-1979 r. Informator, t. 5, opr. J. Patryas, Warszawa 1982, s. 256-257.

${ }^{14}$ J. Knopek, op. cit., s. 212.

15 Stosunki dyplomatyczne..., s. 255. 
nigeryjskim rynku podmiotów krajowych. Jako drogę do realizacji tego celu przedstawiano aktywne zwalczanie wpływów Zachodu oraz zacieśnianie związków z państwami socjalistycznymi ${ }^{16}$.

Ambasada wskazywała na życzliwy odbiór polskich inicjatyw gospodarczych i sygnalizowała szansę na dalszy rozwój tej gałęzi relacji. Głównymi towarami importowanymi były orzechy arachidowe, orzechy palmowe i olej palmowy, jednakże całość obrotów dwustronnych wynosiła zaledwie ok. 1\% handlu zagranicznego Nigerii. Znaczący sukces odniosła Polska Żegluga Morska (PŻM) przełamując monopol państw postkolonialnych i uzyskując ok. 20\% udział w przewozie miejscowych towarów eksportowych. W lipcu 1964 r. rząd w Lagos zaprosił do współpracy polskich ekspertów - głównie lekarzy, wykładowców i inżynierów. Na początku 1965 r. planowano przyjazd pierwszej grupy. Placówka proponowała przygotowanie długofalowego planu udziału ekspertów w pracy na rzecz rozwoju Nigerii. Równocześnie odnotowano wzrost liczby studentów przyjeżdżających na studia do Polski. Ponadto w miejscowej prasie nie odnotowano głosów na temat ewentualnego rasistowskiego traktowania Nigeryjczyków w Polsce, co miało dotychczas miejsce w przypadku innych państw socjalistycznych. Wskazywano na konieczność popularyzacji wiedzy dotyczącej afrykańskiego partnera ${ }^{17}$. Taki obraz stosunków w przededniu kryzysu wewnętrznego dawał stronie polskiej nadzieję na rozwój współpracy zwłaszcza w dziedzinie gospodarczej. Należy podkreślić, iż zarówno aktywność PŻM, jak i kontrakty polskich specjalistów były dla Polski istotnym źródłem dewiz.

Również $\mathrm{w}$ tak odległym od europejskich spraw państwie polska placówka żywo interesowała się tzw. problemem niemieckim, zwłaszcza w kontekście uznania przez Nigerię za niepodważalny przebiegu polskiej granicy zachodniej i północnej. W marcu 1965 r. informowano centralę o aktywności przedstawicielstwa dyplomatycznego Republiki Federalnej Niemiec podkreślając brak jakiejkolwiek interakcji z jej pracownikami. Polscy dyplomaci interweniowali również w miejscowym MSZ protestując przeciwko rozpowszechnianiu przez Niemców map, prezentujących jako istniejącą granicę polsko-niemiecką w kształcie z 1937 r. Przy tej okazji uzyskano zapewnienie, iż w żadnej publikacji oficjalnej rządu nigeryjskiego tego typu mapy nie zostaną wykorzystane. Placówka podkreślała zaangażowanie dziennikarzy i przedsiębiorców zachodnioniemieckich w Nigerii. Jako formę przeciwdziałania tym wpływom ambasador B. Musielak rozważał weryfikację personelu ambasady zachodnioniemieckiej pod kątem przynależności do formacji

${ }^{16}$ Archiwum Ministerstwa Spraw Zagranicznych [dalej: AMSZ] 1965 Dep. V sygn. 55/70 w. 5 Nigeria, Notatka polityczna nt. stosunków polsko-nigeryjskich, 22.01.1965, bp.

17 Ibidem. 
nazistowskich i ewentualne ujawnienie tych faktów społeczności nigeryjskiej. Jednakże, biorąc pod uwagę brak pełnego zrozumienia miejscowej opinii publicznej dla niuansów polityki europejskiej zrezygnowano z tego typu działań ${ }^{18}$. Zaangażowanie ambasady w Lagos w przeciwdziałanie aktywności zachodnioniemieckiej dowodzi znaczenia jakie w latach 60. polska dyplomacja przykładała do tzw. problemu niemieckiego także w kontekście relacji z państwami rozwijającymi się.

Za godne podkreślenia należy uznać zaangażowanie polskich dyplomatów działających w Lagos w zdobywanie szczegółowych informacji dotyczących polityki wewnętrznej państwa przyjmującego w omawianym okresie. Przygotowywane opracowania mają charakter wyczerpujący i oparte są na różnorodnych źródłach ${ }^{19}$. Zachowały się również notatki ze spotkań z politykami nigeryjskimi, a także osobami zbliżonymi do najważniejszych osób w państwie ${ }^{20}$. Przekazywane do Warszawy informacje pozwalały na całościową analizę rozwoju narastającego kryzysu wewnętrznego i na tej podstawie przygotowywanie oficjalnego stanowiska wobec zachodzących wydarzeń.

Po zamachu stanu w styczniu 1966 r. polska ambasada informowała o braku zmian w polityce Nigerii wobec państw socjalistycznych. Nowe władze zamierzały kontynuować politykę niezaangażowania przy równoczesnej gotowości udziału w wielostronnych inicjatywach pokojowych. Stanowisko to wyraził podczas noworocznego spotkania z korpusem dyplomatycznym gen. Ironsi ${ }^{21}$. Taka sytuacja zachęcała zatem do prowadzenia „cierpliwego dialogu" zarówno na forum wielostronnym, jak i w relacjach dwustronnych ${ }^{22}$.

W perspektywie rywalizacji dwublokowej określono Nigerię jako kolejny „front walki”. Co ciekawe szczególną uwagę poświęcono rywalizacji gospodarczej i konieczności przełamania dominacji na miejscowym rynku przedsiębiorstw z kapitałem zachodnim. Z inicjatywy strony polskiej podjęto rozmowy na temat dalszego rozwoju współpracy żeglugowej, w tym usta-

${ }^{18}$ AMSZ 1965 Dep. V sygn. 55/70 w. 5 Nigeria, Pismo ambasadora B. Musielaka do Dyrektora Departamentu V MSZ R. Spasowskiego, 20.01.1965, bp.

${ }^{19}$ AMSZ 1965 Dep. V sygn. 55/70 w. 5 Nigeria, Por. Notatka nt. sytuacji politycznej w Zachodniej Nigerii z dn. 22.03.1965 r., Notatka nt. powyborczej sytuacji politycznej i dodatkowych wyborów w Nigerii, 23.03.1965, bp.

20 AMSZ 1965 Dep. V sygn. 55/70 w. 5 Nigeria, Por. Notatka z rozmowy Amb. B. Musielaka z informatorem z partii NCNC, 4.11.1965; Notatka z rozmowy II Sekretarza Ambasady A. Wójtowicza z redaktorem „Nigeria Tribune”, bratem jednego z Sekretarzy Action Group, 7.11. 1965, bp.

${ }^{21}$ AMSZ 1966 Dep. V sygn. 56/70 w. 5 Nigeria, Tekst przemówienia gen. A. Ironsi'ego na pierwszym spotkaniu z korpusem dyplomatycznym, 28.01.1966, bp.

${ }^{22}$ AMSZ 1966 Dep. V sygn. 56/70 w. 5 Nigeria, Notatka nt. stosunków dwustronnych polsko-nigeryjskich, 5.04.1966, bp. 
nowienia regularnego połączenia komunikacyjnego oraz ułatwień w ruchu osobowym dla przedstawicieli handlowych ${ }^{23}$.

Sytuację wewnętrzną oceniano jako „obiektywnie postępową" wskazując na pewne posunięcia nowych władz godzące w interesy wielkiego kapitału i przeciwdziałające wszechobecnemu dotychczas trybalizmowi ${ }^{24}$. Ambasada w Lagos zwróciła również uwagę na, spowodowane problemami w komunikacji, prezentowanie $\mathrm{w}$ polskich mediach doniesień agencyjnych pochodzących z reguły od korespondentów zachodnich, które nie były dobrze przyjmowane przez nowe władze Nigerii. Postulowano wykorzystanie informacji przekazywanych przez przebywającego na miejscu korespondenta PAP Ryszarda Kapuścińskiego ${ }^{25}$, wskazując na zbieżność jego ocen bieżących wydarzeń ze stanowiskiem placówki ${ }^{26}$.

Lipcowy zamach stanu był dla polskiej dyplomacji, jak zresztą dla całej społeczności międzynarodowej, kolejnym zaskoczeniem. Tym razem jego sprawców łączono z tradycyjnymi plemionami północnymi niechętnymi reformom zapoczątkowanymi przez gen. Ironsi'ego. W informacjach ambasady zwrócono uwagę na szczególny sprzeciw wobec omawianych wydarzeń ze strony gubernatora Regionu Wschodniego ppłk. Ojukwu. Potępienie przez niego zamachu stanu doprowadziło do aktywizacji środowisk separatystycznych otwarcie żądających opuszczenia federacji. Co więcej, zapowiedzi secesji polscy dyplomaci potraktowali jedynie jako taktyczną próbę wzmocnienia pozycji regionu i jego władz, nie zaś realne zagrożenie dla jedności terytorialnej państwa ${ }^{27}$. Ambasador Musielak jednoznacznie opowiadał się za stanowczym uznawaniem jedności Nigerii i w przypadku zaistnienia działań secesjonistycznych popieraniem rządu federalnego ${ }^{28}$.

Niestabilna sytuacja polityczna w roku 1966 nie wpłynęła znacząco na relacje handlowe Polski i Nigerii. Ambasada w swej informacji z narady personelu wskazywała na opieszałość ze strony polskich przedsiębiorstw $\mathrm{w}$ realizacji dotychczasowych zamówień oraz zaniechania $\mathrm{w}$ rozszerzaniu współpracy handlowej. Postulowano większe zaangażowanie $\mathrm{CIECHu}$

23 Ibidem.

24 AMSZ 1966 Dep. V sygn. 56/70 w. 5 Nigeria, Notatka nt. sytuacji w Nigerii po styczniowym przewrocie, 5.04.1966, bp.

25 R. Kapuściński poświęcił wydarzeniom ze stycznia 1966 r. reportaż „Anatomia zamachu stanu” włączony do zbioru „Heban”, R. Kapuściński, Heban, Warszawa 2008, s. 85-91.

26 AMSZ 1966 Dep. V sygn. 56/70 w. 5 Nigeria, Pismo ambasadora B. Musielaka do Dyrektora Departamentu V MSZ R. Spasowskiego, 2.02.1966, bp.

27 AMSZ 1966 Dep. V sygn. 56/70 w. 5 Nigeria, Notatka nt. sytuacji wewnętrznej w Nigerii po nowym zamachu stanu z dnia 29 lipca 1966 r., 8.10.1966, bp.

28 AMSZ 1966 Dep. V sygn. 56/70 w. 5 Nigeria, Protokół z narady personelu placówki z dn. 17.11.1966, bp. 
w sprzedaży farmaceutyków. Ze względu na brak możliwości przewozowych nie doszła do skutku dostawa dużej partii cementu przez centralę MINEX, zaś UNIWERSAL stracił odbiorców na cieszące się w Nigerii dużą renomą wiadra ocynkowane ${ }^{29}$. Jakkolwiek zwłaszcza kwestia ostatniego kontraktu może być z perspektywy współczesnego czytelnika mało istotna to należy pamiętać, iż w latach 60. na rynkach afrykańskich powodzeniem cieszyły się produkty niezaawansowane technicznie, cechujące się długim okresem eksploatacji. Takie właśnie towary oferował polski przemysł.

Polska polityka wobec narastającego kryzysu wewnętrznego w Nigerii charakteryzowała się poparciem dla jedności kraju i motywowana była z jednej strony chęcią zachowania dotychczasowych dobrych relacji w sferze gospodarczej oraz ideologicznym wsparciem "dojrzałego" stanowiska władz federalnych w zakresie walki z „imperializmem”, neokolonializmem i trybalizmem. Szczególną wagę przywiązywano do kontynuowania współpracy w ramach żeglugi realizowanej przez polsko-enerdowską spółkę UNIAFRICA $^{30}$. Należy zauważyć, iż takie stanowisko w pełni zabezpieczało polskie interesy przy równoczesnym czynieniu zadość ideologicznej polityce bloku wschodniego w Afryce Zachodniej.

\section{Polska wobec konfliktu biafrańskiego}

W połowie 1967 r., a więc w najgorętszym okresie kryzysu nigeryjskiego, zakończyła się kadencja polskiego ambasadora w Lagos B. Musielaka. W swym sprawozdaniu szczegółowo analizował sytuację w kraju przyjmującym, podkreślając elementy łączące interesy Polski i Nigerii na arenie międzynarodowej. Dokument, napisany jeszcze przed secesją Regionu Wschodniego, jednoznacznie rekomendował popieranie działań rządu federalnego na rzecz zachowania jedności terytorialnej państwa ${ }^{31}$. Dotychczasowa praca ambasadora, zwłaszcza oceny i prognozy polityczne, były bardzo wysoko oceniane przez centralę ${ }^{32}$.

Rząd Polski został oficjalnie poinformowany o stanowisku zwierzchników federalnych Nigerii wobec secesji Regionu Wschodniego w liście skierowanym przez płk. Y. Gowona do premiera Józefa Cyrankiewicza datowanym na 31 maja 1967 r. Przywódca nigeryjski przedstawiał dotychczasowe

\footnotetext{
${ }^{29}$ Ibidem.

${ }^{30}$ AMSZ, 1967 Dep. V sygn. 57/70 w. 4 Nigeria, Notatka nt. stosunków polsko-nigeryjskich, 5.04.1967, bp.

31 AMSZ, 1967 Dep. V sygn. 57/70 w. 4 Nigeria, Sprawozdanie ambasadora B. Musielaka - sytuacja polityczna w Nigerii, przed 10.06.1967, bp.

${ }^{32}$ AMSZ, 1967 Dep. V sygn. 57/70 w. 4 Nigeria, Ocena sprawozdania ambasadora Musielaka po powrocie z Nigerii, 18.07.1967, bp.
} 
wysiłki na rzecz deeskalacji kryzysu politycznego oraz apelował o nieuznawanie niepodległości Biafry ${ }^{33}$. Departament V MSZ informował kierownictwo resortu o braku konieczności odpowiedzi na list ${ }^{34}$. Równocześnie kryzys wokół secesji uznano za niekorzystny dla rozwoju państwowości, gospodarki i postępowych sił społecznych Nigerii ${ }^{35}$. Prognozowano wybuch wojny domowej, a nawet, w przypadku powodzenia secesji, rozpad państwa. Podkreślono negatywne skutki, jakie przykład Biafry mógł nieść dla całego kontynentu, na którym większość państw posiadała strukturę wieloetniczną. Informowano o możliwości poparcia separatystów przez USA, ale dopiero po uznaniu Biafry przez część państw afrykańskich. Celem zabezpieczenia polskich interesów, zwłaszcza gospodarczych, proponowano przyjęcie postawy wyczekującej $^{36}$.

W poszukiwaniu polskiego poparcia dla swej sprawy aktywniejszy od rządu federalnego był ppłk Ojukwu. Pierwszy list do I Sekretarza KC PZPR Władysława Gomułki skierował w kwietniu 1967 r. Informował w nim, iż wobec napływu imigrantów oraz pogarszającej się sytuacji gospodarczej wprowadzenie przez władze federalne blokady ekonomicznej lub podjęcie działań zbrojnych będzie uznane za wykluczenie Regionu Wschodniego z federacji. Departament V podjął decyzję o poinformowaniu o liście polskiej ambasady w Lagos oraz przekazaniu instrukcji, w której nakazywano charge d'affaires Andrzejowi Wójtowiczowi powstrzymanie się od relacji z władzami prowincji, zaś w przypadku niespodziewanego kontaktu polecono uznanie kwestii poruszonych w liście za wewnętrzną sprawę Nigerii ${ }^{37}$.

Kolejny list przywódcy Biafry przekazano za pośrednictwem ambasady w Londynie 20 czerwca. Polityk określał w nim rząd federalny, jako „kukłę brytyjskiego neokolonializmu" oraz oskarżał go o zbrodnie przeciwko ludzkości. Równocześnie proponował, jako polityczne rozwiązanie konfliktu, utworzenie na gruzach państwa federalnego luźnej konfederacji połączonej wspólnym rynkiem. W odniesieniu do relacji z Polską chciał je oprzeć na gruncie postanowień Karty Narodów Zjednoczonych ${ }^{38}$. Zastosowanie

${ }^{33}$ AMSZ, 1967 Dep. V sygn. 57/70 w. 4 Nigeria, Tłumaczenie telegramu ppłk. Y. Gowona do J. Cyrankiewicza, 31.05.1967, bp.

${ }^{34}$ Dep. V sygn. 57/70 w. 4 Nigeria, Pismo S. Wilskiego z Departamentu V do wiceministra M. Naszkowskiego, 2.06.1966, 1967, bp.

35 AMSZ, 1967 Dep. V sygn. 57/70 w. 4 Nigeria, Notatka dot. aktualnej sytuacji w Nigerii, 1.06.1967, bp.

${ }^{36}$ Ibidem.

${ }^{37}$ AMSZ, 1967 Dep. V sygn. 60/70 w. 2 Nigeria, Pilna notatka S. Wilskiego z Departamentu V MSZ do ambasadora Michałowskiego, 26.04.1967, bp.

${ }^{38}$ AMSZ, 1967 Dep. V sygn. 60/70 w. 2 Nigeria, Tłumaczenie listu Gubernatora Wojskowego Republiki Biafry ppłk. O. Ojukwu do I Sekretarza KC PZPR Władysława Gomułki, 30.05.1967, bp. 
frazeologii o „antyimperialistycznym” charakterze nowego państwa miało wpłynąć na pozytywne przyjęcie listu przez władze w Warszawie. Jednakże i tym razem postanowiono nie odpowiadać na posłanie, jedynie informując o fakcie wpłynięcia listu ambasadę w Lagos ${ }^{39}$.

W drugiej połowie sierpnia 1967 r., za pośrednictwem ambasady PRL w Paryżu, do MSZ wpłynął list ppłk. Ojukwu informujący o skierowaniu do Polski trzyosobowej delegacji, której celem miało być wszechstronne omówienie wzajemnych stosunków obu podmiotów ${ }^{40}$. Niestety w zasobach Archiwum MSZ nie zachowały się dokumenty informujące czy wizyta taka doszła do skutku. Jednakże biorąc pod uwagę nieuznawanie przez Polskę Republiki Biafry, należy uznać to za mało prawdopodobne.

Sytuacja w Nigerii była przedmiotem konsultacji z innymi państwami socjalistycznymi na różnym szczeblu. Gubernator Regionu Wschodniego szukał możliwości bezpośredniego kontaktu z państwami socjalistycznymi. Jego osobisty wysłannik przybył do NRD na początku stycznia 1967 r. Podczas rozmów z urzędnikami Wydziału Afrykańskiego wschodnioniemieckiego MSZ zadeklarował, w razie ogłoszenia niepodległości, zerwanie powiązań gospodarczych z przedsiębiorstwami zachodnimi i nawiązanie współpracy z państwami socjalistycznymi w zamian za poparcie polityczne i pomoc techniczną. Ostatecznie NRD postanowiła wysłać do Nigerii Wschodniej misję techniczną, jednak odmówiła dostaw broni dla secesjonistów. Strona polska została poinformowana o spotkaniu dopiero na początku maja ${ }^{41}$.

3 czerwca 1967 r. polski MSZ został zawiadomiony przez I sekretarza ambasady Czechosłowacji o liście wysłanym do premiera tego kraju przez ppłk. Gowona. Nigeryjski przywódca apelował o nieuznawanie niepodległości Biafry. Administracja czechosłowacka nie zamierzała odpowiadać na posłanie i równocześnie zapewniła stronę polską o braku woli uznania secesjonistycznej republiki. Czechosłowacki dyplomata uzyskał zapewnienie o identycznym stanowisku Polski w przedmiotowej sprawie ${ }^{42}$.

Wymierną pomoc dla władz federalnych stanowiły radzieckie i czechosłowackie dostawy uzbrojenia, w szczególności samolotów mig-19, dzięki

${ }^{39}$ AMSZ, 1967 Dep. V sygn. 60/70 w. 2 Nigeria, Pismo S. Wilskiego z Departamentu V do wiceministra J. Winiewicza, 7.07.1967, bp.

40 AMSZ, 1967 Dep. V sygn. 57/70 w. 4 Nigeria, List Wojskowego Gubernatora Republiki Biafry ppłk. O. Ojukwu do Ministra Spraw Zagranicznych PRL, 6.08.1967, bp.

${ }^{41}$ AMSZ, 1967 Dep. V sygn. 57/70 w. 4 Nigeria, Notatka na temat wizyty w NRD osobistego wysłannika Gubernatora Wojskowego Wschodniej Nigerii, 15.05.1967, bp.

42 AMSZ, 1967 Dep. V sygn. 57/70 w. 4 Nigeria, Notatka z rozmowy z I Sekretarzem Ambasady CSRS w Warszawie, Tow. M. Sperlingiem, przeprowadzonej w Departamencie V w dniu $3 \mathrm{bm}$. - z inicjatywy strony czeskiej, 5.06.1967, bp. 
którym strona rządowa uzyskała przewagę techniczną nad separatystami ${ }^{43}$. Jednakże postawę Czechosłowacji strona polska określała jako czysto „komercyjną", ponieważ najpierw sprzedała ona uzbrojenie siłom biafrańskim. Także w wymiarze politycznym Praga starała się przekonać Moskwę o postępowym charakterze secesji Biafry ${ }^{44}$, jednak z zachowanych źródeł wynika, iż polski MSZ nie wiedział o takich zabiegach. Ostatecznie Czechosłowacja porzuciła wspieranie separatystów i zawarła kontrakty z rządem federalnym. W lipcu 1967 r. PŻM otrzymała z Czechosłowacji ofertę przewozu 115 ton ładunku statkiem m/s „Kraków” ze Szczecina do Lagos ${ }^{45}$. Oficjalnie towar eksportować miała firma szwajcarska. Ministerstwo Żeglugi, zainteresowane pozyskaniem kontraktu wystąpiło o zatwierdzenie transakcji do MSZ, które nie wyraziło sprzeciwu ${ }^{46}$. Kolejny, transport tym razem 90 ton na pokładzie m/s „Rzeszów”, konsultowany był we wrześniu ${ }^{47}$.

Wraz z upływem czasu oceny polskiej ambasady dotyczące konfliktu stawały się bardziej stanowcze. Niemal miesiąc po ogłoszeniu secesji Biafry oceniano to wydarzenie jako negatywne i „reakcyjne”. Za głównych inspiratorów kryzysu uznano polityków „ekstremistycznych i skorumpowanych”, których wpływy chciał ograniczyć rząd centralny. Z perspektywy ideologicznej analizowano wpływ secesji na rozwój miejscowego ruchu robotniczego, który popierając niepodległość regionu mógł być w dalszym etapie zniszczony przez „kompradorską burżuazję”. W notatce zawarto również analizę politycznego położenia rządu federalnego, który tracąc możliwość zachowania równowagi społecznej musiał polegać na wsparciu regionów północnych ${ }^{48}$.

Rotacja na stanowisku szefa misji skutkowała koniecznością wprowadzenia w sytuację w kraju przyjmującym jego następcy, co w obliczu labilności sytuacji, odbiło się na zdolności placówki do pozyskiwania ważnych informacji. Niestety treść notatki z początku grudnia 1967 r. wskazuje, iż nowy ambasador Mieczysław Dedo niezbyt dobrze orientował się w niuansach

${ }^{43}$ AMSZ, 1967 Dep. V syg. 57/70 w. 4 Nigeria, Notatka nt. nowych elementów w kryzysie nigeryjskim, 19.10.1967, bp.

${ }_{44}$ P. Muehlenbeck, Czechoslovakia in Africa, 1945-1968, London 2016, s. 119-121.

${ }^{45}$ AMSZ, 1967 Dep. V sygn. 60/70 w. 2 Nigeria, Pismo dyrektora Departamentu Polityki Morskiej i Współpracy z Zagranicą (dalej: DPMiWZ) Ministerstwa Żeglugi S. Samolewicza do dyrektora Departamentu V MSZ S. Wilskiego, 20.07.1967, bp.

${ }^{46}$ AMSZ, 1967 Dep. V sygn. 60/70 w. 2 Nigeria, Pismo dyrektora DPMiWZ Ministerstwa Żeglugi S. Samolewicza do K. Korolczyka z Departamentu V MSZ, 26.07.1967, bp.

47 AMSZ, 1967 Dep. V sygn. 60/70 w. 2 Nigeria, Pismo dyrektora DPMiWZ Ministerstwa Żeglugi S. Samolewicza do Departamentu V MSZ, 8.09.1967 r., bp.

${ }^{48}$ AMSZ, 1967 Dep. V sygn. 57/70 w. 4 Nigeria, Notatka II Sekretarza A. Wójtowicza nt. sytuacji wewnętrznej Nigerii w okresie kwiecień-czerwiec 1967, 24.06.1967, bp. 
polityki nigeryjskiej. W przeciwieństwie do swego poprzednika dużą wagę przywiązywał do zagadnień ideologicznej rywalizacji z państwami kapitalistycznymi. Liczne odręczne notatki na marginesie dokumentu sporządzone w Departamencie V MSZ świadczą o zastrzeżeniach centrali do okresowego raportu placówki ${ }^{49}$.

W połowie 1968 r. Nigeria rozpoczęła ofensywę dyplomatyczną zmierzającą do umocnienia poparcia państw socjalistycznych. Z jej perspektywy Polska jawiła się jako istotny partner dysponujący pewnymi wpływami w organizacjach międzynarodowych, zwłaszcza należącymi do systemu Narodów Zjednoczonych, a także dysponujący interesującym w perspektywie kooperacji potencjałem gospodarczym. 27 czerwca w Belwederze przewodniczący Rady Państwa marszałek Marian Spychalski przyjął specjalnego wysłannika rządu nigeryjskiego w osobie, akredytowanego również w Polsce, ambasadora w ZSRR G.T. Kurubo. Afrykański dyplomata uzyskał zapewnienie władz polskich o poparciu integralności terytorialnej jego państwa i uznaniu konfliktu za jego wewnętrzną sprawę ${ }^{50}$. Przyjmując takie stanowisko, strona polska kierowała się głównie obawą, iż rozczłonkowanie młodego państwa może z jednej z strony stanowić niebezpieczny precedens w kontekście całego kontynentu afrykańskiego, z drugiej zaś ułatwi neokolonialną penetrację tego obszaru przez kapitał zachodni.

Kolejne istotne wydarzenie w stosunkach bilateralnych stanowiła wizyta w dniach 20-24 lipca 1968 r. delegacji rządu federalnego Nigerii na czele z Komisarzem Spraw Zagranicznych dr Okoi Arikpo. Najważniejszym formalnym punktem pobytu była audiencja u marszałka Spychalskiego. Szczegółowe rozmowy polityczne i gospodarcze przeprowadzono z wicepremierem Eugeniuszem Szyrem, a także w MSZ i Ministerstwie Handlu Zagranicznego oraz w Komitecie Współpracy Gospodarczej z Zagranicą. Za głównym cel strona nigeryjska uznawała przedstawienie dotychczasowego przebiegu kryzysu wewnętrznego z perspektywy władz centralnych oraz pozyskanie polskiego wsparcia dla ich działań. Gospodarze zapewnili o poparciu dla integralności terytorialnej Nigerii oraz wyrazili nadzieję na pokojowe rozstrzygnięcie konfliktu. Polski MSZ nie przewidywał jednak zgody na sprzedaż broni, ponieważ uznano tego typu krok za politycznie nie wskazany ${ }^{51}$.

${ }^{49}$ AMSZ, 1967 Dep. V sygn. 57/70 w. 4 Nigeria, Notatka ambasadora M. Dedo nt. nowych zjawisk w kryzysie nigeryjskim, $6.12 .1967 \mathrm{r}$., bp.

${ }^{50}$ AMSZ, 1968 Dep. V sygn. 31/66 w. 4 Nigeria, Notatka dot. wizyty w Polsce amb. G.T. Kurubo, specjalnego wysłannika szefa rządu Federacji Nigerii gen. Y. Gowona, 24.06.1968, bp.

${ }^{51}$ AMSZ, 1968 Dep. V sygn. 31/66 w. 4 Nigeria, Propozycje i uwagi do rozmów z delegacją nigeryjską, 17.07.1968, bp. 
W odniesieniu do problemów gospodarczych podjęto decyzję o wysłaniu do Afryki grupy ekspertów celem przedyskutowania szczegółowych zagadnień. Ponadto komisarz Arikpo poinformował o możliwym otwarciu w Warszawie nigeryjskiej ambasady. Program kulturalny obejmował zwiedzanie Krakowa oraz wizytę w niemieckim obozie zagłady Auschwitz ${ }^{52}$. Była to pierwsza bilateralna wizyta na szczeblu ministrów spraw zagranicznych, co ważne doszła do skutku z inicjatywy strony nigeryjskiej poszukującej silniejszego poparcia w obliczu licznych oskarżeń o zbrodnie wojenne dokonywane na rebeliantach. Podziękowania za przyjęcie delegacji na ręce marszałka Spychalskiego złożył telegraficznie, awansowany na stopień generała majora, Y. Gowon ${ }^{53}$.

W rocznym raporcie politycznym polskiej ambasady na okres od maja 1967 r. do czerwca 1968 r., obok wszechstronnej analizy sytuacji w państwie przyjmującym, znajduje się wzmianka o aktywizacji Towarzystwa Przyjaźni Nigeria-Polska ${ }^{54}$. Centralę zainteresowała motywacja działaczy organizacji, ponieważ za mało prawdopodobną inspirację uznano jedynie polską pomoc stypendialną i aktywność propagandową ambasady ${ }^{55}$.

Świadectwem postępującego zbliżenia poglądów państw socjalistycznych, w tym Polski i Nigerii, była reakcja rządu federalnego na interwencję wojsk Układu Warszawskiego w Czechosłowacji. Lagos przyjęło tę decyzję ze zrozumieniem i uznało za konieczną w zaistniałych okolicznościach politycznych $^{56}$.

Sytuacja wokół kryzysu nigeryjskiego ulegała umiędzynarodowieniu, $\mathrm{w}$ związku z tym polska dyplomacja śledziła rozmowy na jego temat na forach wielostronnych. Jednym z nich była Organizacja Jedności Afrykańskiej. Secesja Biafry stanowiła jeden z głównych tematów podczas konferencji Organizacji w Algierze w dniach 13-16 września 1968 r. Dyplomacja federalna dążyła do uzyskania jak najszerszego poparcia członków organizacji dla akcji pacyfikacyjnej w zbuntowanej prowincji. Jej zabiegi uwieńczone zostały sukcesem, ponieważ aż 33 państwa poparły rezolucję

52 AMSZ, 1968 Dep. V sygn. 31/66 w. 4 Nigeria, Pilna notatka nt. wizyty Komisarza Spraw Zagranicznych Nigerii, 24.08.1968, bp.

${ }^{53}$ AMSZ, 1968 Dep. V sygn. 31/66 w. 4 Nigeria, Telegram Szefa Federalnego Rządu Wojskowego gen. mjr. Y. Gowona do Przewodniczącego Rady Państwa PRL marsz. M. Spychalskiego, 1.08.1968, bp.

${ }^{54}$ AMSZ, 1968 Dep. V sygn. 31/66 w. 4 Nigeria, Raport polityczny Ambasady PRL w Lagos za okres od 30.05.1967 r. do 1.06.1968 r., bp.

55 AMSZ, 1968 Dep. V sygn. 31/66 w. 4 Nigeria, Pismo dyrektora Departamentu V MSZ S. Wilskiego do Ambasady PRL w Lagos, 22.08.1968, bp.

56 AMSZ, 1968 Dep. V sygn. 31/66 w. 4 Nigeria, Notatka nt. ostatnich wydarzeń, związanych z obecnym etapem kryzysu nigeryjskiego, 29.08.1968, bp. 
potwierdzającą konieczność zachowania jedności terytorialnej Nigerii. Przeciw były uznające Biafrę Tanzania, Zambia, Gabon i Wybrzeże Kości Słoniowej, zaś Rwanda i Botswana wstrzymały się od głosu. Podczas szczytu za zachowaniem stanu sprzed wybuchu konfliktu wypowiedział się Sekretarz Generalny ONZ U Thant ${ }^{57}$.

Zbliżające się zwycięstwo strony rządowej oceniano w polskiej ambasadzie jako czynnik konsolidujący Nigeryjczyków poprzez asumpt do budowy wspólnej świadomości narodowej. Równocześnie, z perspektywy znaczenia dla ogólnoświatowej rywalizacji z państwami kapitalistycznymi, uważano konflikt za korzystny dla państw socjalistycznych, które jednoznacznie poparły władze Lagos, sprzeciwiając się secesji Biafry ${ }^{58}$.

$\mathrm{Na}$ polepszenie komunikacji w stosunkach dwustronnych wpłynęło otwarcie 23 maja 1969 r. w Warszawie nigeryjskiej ambasady. Początkowo kierował nią charge d'affaires ad interim Harmachis Dalhato Kolo ${ }^{59}$. Podczas wizyty w MSZ na początku czerwca 1969 r. poinformował o sytuacji na froncie walki z separatystami - wojnę domową uznał za niemal zakończoną. Dyplomata zapytał również, czy Polska byłaby skłonna udzielić pomocy wojskowej w postaci dostaw sprzętu, a także skierowania pilotów do walki po stronie rządu federalnego. Wobec polskiej polityki niezaangażowania w konflikt otrzymał odpowiedź odmowną ${ }^{60}$.

Bliska perspektywa zakończenia konfliktu dawała stronie polskiej szansę udziału w odbudowie zniszczonych terenów oraz nowych projektach gospodarczych planowanych przez rząd w Lagos. Centrala Handlu Zagranicznego CEKOP miała wziąć udział w przetargach na budowę fabryk rowerów, wanien emaliowanych oraz ceramiki sanitarnej i stołowej. Biuro radcy handlowego proponowało również rozpoczęcie współpracy w zakresie górnictwa i eksportu towarów przemysłu motoryzacyjnego. Cały czas wzrastała liczba polskich specjalistów pracujących na kontraktach, osiągając liczbę ponad stu. W dziedzinie gospodarki morskiej planowano uruchomienie mieszanej spółki połowowej. Nigerię po raz kolejny uznano za szczególnie interesujący rynek ze względu na możliwość pozyskiwania dewiz ${ }^{61}$.

${ }^{57}$ AMSZ, 1968 Dep. V sygn. 31/66 w. 4 Nigeria, Notatka nt. konfliktu nigeryjskiego podczas konferencji na szczycie OJA w Algierze, 7.10.1968, bp.

${ }^{58}$ AMSZ, 1969 Dep. V sygn. 18/73 w. 2 Nigeria, Notatka nt. aktualnych węzłowych problemów sytuacji wewnętrznej Nigerii, 15.02.1969, bp.

59 Stosunki dyplomatyczne..., s. 255.

${ }^{60}$ AMSZ, 1969 Dep. V sygn. 18/73 w. 2 Nigeria, Pilna notatka z rozmowy z charge d'affaires Nigerii w Warszawie, 4.06.1969, bp.

${ }^{61}$ AMSZ, 1969 Dep. V sygn. 18/73 w. 2 Nigeria, Protokół z narady zorganizowanej w dn. 23.06.1969 r. z udziałem pracowników merytorycznych Ambasady, BRH, Daltrade i przedstawiciela PŻM, bp. 
Dalszy rozwój współpracy był przedmiotem rozmów jaką w ostatniej dekadzie września 1969 r. odbył w Ministerstwie Przemysłu Ciężkiego nigeryjski minister transportu Joseph Serwuan Tarka. Gość szczególne zainteresowanie wyraził zakupem w Polsce wagonów towarowych i statków rybackich, zaś gospodarze zgłosili zapotrzebowanie na import rud metali ${ }^{62}$. Delegacja zwiedzała porty i stocznie w Trójmieście i w Płocku. Uczestniczyła również w spotkaniach w MHZ i Ministerstwie Żeglugi. Podczas rozmów politycznych w Departamencie V MSZ omówiono sytuację wewnętrzną oraz stosunki polityczne w Afryce ${ }^{63}$.

Strona polska w 1969 r., zaangażowała się również w pomoc humanitarną dla Nigerii. Początkowo planowano przekazanie tony mleka w proszku za pośrednictwem Międzynarodowego Komitetu Czerwonego Krzyża ${ }^{64}$. Jednakże ambasada w Lagos zasugerowała przysłanie, zamiast niewykorzystywanego na miejscu mleka w proszku, koców i to bezpośrednio od PCK do Nigeryjskiego Czerwonego Krzyża ${ }^{65}$. Taka procedura dostawy pomocy związana była z oskarżeniami kierowanymi przez rząd federalny pod adresem organizacji humanitarnych, a dotyczącymi materialnego wspierania rebeliantów.

Wydarzenia w Nigerii budziły także zainteresowanie polskich dziennikarzy. Obok wspomnianego już Ryszarda Kapuścińskiego wyprawę do Afryki Zachodniej podjęła red. Genowefa Czekała z miesięcznika „Kontynenty". W swym sprawozdaniu opisała m.in. podróż do strefy przyfrontowej w Biafrze ${ }^{66}$. Owocem wyprawy była książka Bellona nad Zatokq Gwinejskq̨ ${ }^{67}$. Należy zauważyć, iż polskie media prezentowały zbieżny ze stanowiskiem dyplomacji obraz konfliktu w Biafrze.

\section{Udział Polaków w Międzynarodowej Grupie Obserwatorów}

Pojawiające się w światowych serwisach informacyjnych doniesienia o zbrodniach wojennych popełnianych przez wojska federalne zmusiły władze w Lagos do podjęcia działań zmierzających do wyjaśnienia problemu przez

${ }^{62}$ AMSZ, 1969 Dep. V sygn. 18/73 w. 2 Nigeria, Notatka z rozmowy przeprowadzonej przez podsekretarza stanu w MPC mgr. inż. T. Markowskiego z Ministrem Transportu Nigerii J.S. Tarką, 24.10.1969, bp.

${ }^{63}$ AMSZ, 1969 Dep. V sygn. 18/73 w. 2 Nigeria, Notatka z rozmowy z Komisarzem Transportu rządu federalnego Nigerii J.S. Tarką, 29.09.1969, bp.

${ }^{64}$ AMSZ, 1969 Dep. V sygn. 19/73 w. 1 Nigeria, Szyfrogram nr 6257 do ambasady w Lagos, 24.07.1969, bp.

${ }^{65}$ AMSZ, 1969 Dep. V sygn. 19/73 w. 1 Nigeria, Szyfrogram nr 8319 z Lagos, 26.07.1969, bp.

${ }^{66}$ AMSZ, 1969 Dep. V sygn. 18/73 w. 2 Nigeria, Sprawozdanie G. Czekały z podróży do Afryki, 20.05.1969, bp.

67 G. Czekała-Mucha, Bellona nad Zatokq Gwinejska, Warszawa 1981. 
bezstronnych obserwatorów. Prośbę o przesyłanie personelu misji obserwacyjnej skierowano do Wielkiej Brytanii, Kandy, Szwecji, Organizacji Jedności Afrykańskiej i ONZ. Początkowo rząd Nigerii planował złożenie propozycji udziału w grupie przedstawicielom ZSRR, jednak obawiając się bojkotu tego gremium przez państwa zachodnie protestujące przeciwko interwencji w Czechosłowacji, wycofał się z tego pomysłu. Równocześnie, uznając głębokie zrozumienie istoty kryzysu zaproponowano zaangażowanie w misję Polsce ${ }^{68}$.

Informację o możliwości uczestnictwa w grupie przekazano polskiej ambasadzie 30 sierpnia 1968 r. MSZ sugerował kierownictwu państwa zgodę na udział przedstawiciela w tym przedsięwzięciu, jednak pod pewnymi warunkami: zgody innych państw na udział w misji, przyczynienia się działań grupy do poprawy sytuacji humanitarnej ludności cywilnej na objętych walkami terenach oraz nieingerencji w wewnętrzne sprawy Nigerii ${ }^{69}$. Niestety w zasobach Archiwum MSZ nie zachowały się dokumenty świadczące o przebiegu procesu decyzyjnego w tym zakresie.

Celem Międzynarodowej Grupy Obserwatorów (dalej: MGO) była weryfikacja zarzutów separatystów wobec władz federalnych o ludobójstwo na przedstawicielach Ibów. Przedstawiciele Kanady i Wielkiej Brytanii proponowali rozszerzenie aktywności MGO o dalsze nadzorowanie przestrzegania praw i zwyczajów wojennych przez strony konfliktu. Departament V MSZ wypowiadał się jednak stanowczo przeciw, uważając, że w przypadku niekorzystnego dla strony federalnej przebiegu wojny aktywność obserwatorów mogłaby być dla niej niekorzystna politycznie ${ }^{70}$.

Pierwszym polskim przedstawicielem $\mathrm{w}$ grupie został mianowany płk Alfons Olkiewicz, któremu pomagali Tadeusz Kumanek i ppor. Michał Byczy. Na uwagę zwraca doświadczenie płk. Olkiewicza, który w latach 1946-1949 był zastępcą attaché wojskowego w USA, zaś później członkiem Komisji Nadzoru i Kontroli w Laosie. Od 12 sierpnia 1969 r. obowiązki polskiego obserwatora przejął płk Józef Biernacki ${ }^{71}$. Na początku października por. Byczego zastąpił ppłk Kazimierz Grymin ${ }^{72}$. Oficerowie uczestniczący

${ }^{68}$ AMSZ, 1968 Dep. V sygn. 31/66 w. 4 Nigeria, Notatka nt. nowych zjawisk w sytuacji politycznej Nigerii, 15.10.1968, bp.

69 AMSZ, 1970 Dep. V sygn. 26/74 w. 1 Nigeria, Pilna notatka nt. udziału Polski w Międzynarodowej Grupie Obserwatorów, 30.08.1968, paginacja wielokrotna.

${ }^{70}$ AMSZ, 1969 Dep. V sygn. 19/73 w. 1 Nigeria, Notatka nt. międzynarodowej grupy obserwatorów w Nigerii, 10.02.1969, bp.

${ }^{71}$ AMSZ, 1970 Dep. V sygn. 26/74 w. 1 Nigeria, Raport nr 4 obserwatora PRL w Nigerii, 15.08.1969, bp.

${ }^{72}$ AMSZ, 1970 Dep. V sygn. 26/74 w. 1 Nigeria, Raport nr 5 obserwatora PRL w Nigerii, 10.1969, bp. 
w MGO, obok pracy nad wspólnymi dokumentami grupy, przygotowali sześć obszernych raportów dla MSZ i Jednostki Wojskowej nr 200073, informujących nie tylko o działalności grupy, ale również o całokształcie sytuacji w Nigerii. Raporty, przygotowywane co dwa miesiące, zawierały dane niewchodzące w zakres mandatu grupy, zatem pomijane w oficjalnych dokumentach MGO. Załączniki do dokumentów stanowiły mapy prezentujące położenie na froncie wojsk stron konfliktu. Ponadto, za pośrednictwem polskiej ambasady, przesyłano do MSZ notatki dotyczące bieżącego funkcjonowania grupy i jej spotkań z politykami zagranicznymi ${ }^{74}$.

MGO rozpoczęła swą działalność 24 września 1968 r. Wszyscy jej członkowie już w pierwszym okresie swej aktywności w Nigerii stwierdzili bezpodstawność zarzutów ludobójstwa kierowanych pod adresem rządu federalnego przez secesjonistów. Spory miedzy oficerami dotyczyły kwestii proceduralnych oraz możliwości ewentualnego rozszerzania mandatu MGO. Obserwatorzy posiadali swobodny dostęp do strefy frontowej, mogli rozmawiać z żołnierzami, jeńcami oraz ludnością cywilną ${ }^{75}$. W drugim raporcie pojawiają się informacje o zbrodniach wojennych popełnianych przez stronę secesjonistyczną na jeńcach i ludności należącej do mniejszości etnicznych. Co ciekawe polski przedstawiciel powołuje się na wiarygodne zeznania świadków potwierdzające w tym kontekście przypadki kanibali$\mathrm{zmu}^{76}$. Kolejne sprawozdanie zawierało doniesienie o dostawach broni dla Biafry realizowanych pod przykrywką pomocy humanitarnej dostarczanej przez organizacje charytatywne kościołów chrześcijańskich ${ }^{77}$. W ostatnich dwóch raportach sporządzonych przez płk. Biernackiego znaczną część stanowią charakterystyki członków MGO i uwag dotyczące działań tego gremium $^{78}$.

W swych wspomnieniach płk Olkiewicz przytacza liczne anegdoty związane z pracą grupy. W jego ocenie stosunki między współpracującymi ze sobą oficerami z różnych państw były koleżeńskie i nie sprawiały trudności.

${ }^{73}$ Pod tą nazwą krył się Zarząd II Sztabu Generalnego Wojska Polskiego odpowiedzialny za działalność rozpoznawczą.

${ }^{74}$ AMSZ, 1969 Dep. V sygn. 19/73 w. 1 Nigeria, Notatka służbowa ze spotkania Międzynarodowej Grupy Obserwatorów w Nigerii z premierem Wielkiej Brytanii H. Wilsonem, 30.03.1969, bp.

75 AMSZ, 1970 Dep. V sygn. 26/74 w. 1 Nigeria, Raport nr 1 obserwatora PRL w Nigerii, 15.02.1969, paginacja wielokrotna.

${ }^{76}$ AMSZ, 1970 Dep. V sygn. 26/74 w. 1 Nigeria, Raport nr 2 obserwatora PRL w Nigerii, 29.04.1969, paginacja wielokrotna.

77 AMSZ, 1970 Dep. V sygn. 26/74 w. 1 Nigeria, Raport nr 3 obserwatora PRL w Nigerii, 30.06.1969, paginacja wielokrotna.

${ }^{78}$ AMSZ, 1970 Dep. V sygn. 26/74 w. 1 Nigeria, Raport nr 5 obserwatora PRL w Nigerii, 10.1969, bp; Raport nr 6 obserwatora PRL w Nigerii, 2.1970, paginacja wielokrotna. 
Problemami był jedynie gorący klimat Nigerii oraz zdarzające się niebezpieczne sytuacje na obszarach przyfrontowych. Podczas swej misji spotykał weteranów Polskich Sił Zbrojnych na Zachodzie pracujących na rzecz strony federalnej ${ }^{79}$. Autor artykułu wspomnieniowego nie opisuje szczegółów pracy MGO, o których informował w swych raportach.

Bezwarunkowa kapitulacja Biafry 15 stycznia 1970 r. wiązała się również z zakończeniem misji MGO. Wobec konieczności przygotowania ostatniego raportu jej członkowie mieli przebywać w Nigerii do końca lutego ${ }^{80}$. Zakończenie działalności grupy uwieńczone było uroczystym obiadem, jaki na jej cześć wydał nigeryjski przywódca gen. Gowon. W jego trakcie, w rozmowie z ambasadorem Dedą gospodarz prosił o przekazanie podziękowań władzom polskim oraz chwalił zaangażowanie pułkowników Olkiewicza i Biernackiego w pracę misji ${ }^{81}$.

\section{Zakończenie}

Afryka, podobnie jak cały ówczesny świat, była obszarem rywalizacji państw kapitalistycznych z państwami socjalistycznymi. Całokształt polityki Polski Ludowej wobec państw Afryki Subsaharyjskiej należy zatem rozpatrywać w kontekście blokowego podporządkowania Związkowi Radzieckiemu. W zależności od okresu miało ono różne przejawy - od wprost formułowanych poleceń po konsultacje i koordynację stanowisk. Polskie zaangażowanie regionie było zdecydowanie mniejsze, niż na przykład NRD czy Czechosłowacji, co wynikało ze znacznej dozy nieufności jaką na Kremlu żywiono wobec ideologicznej postawy decydentów w Warszawie.

Polska od początku kryzysu wewnętrznego w Nigerii przyjęła ostrożną postawę popierając jedność państwa. Za korzystniejsze od wiary w „postępowe" polityczne deklaracje secesjonistów uznano popieranie władz federalnych, z którymi utrzymywano korzystne relacje gospodarcze. Ewentualny rozpad Nigerii uważano za niebezpieczny precedens godzący w podstawy stabilności całego kontynentu afrykańskiego opierające się na zasadzie niepodważania granic wytyczonych w okresie kolonialnym. W realizacji tej polityki wykorzystywano środki polityczne i gospodarcze.

Taka postawa spotkała z bardzo dobrym przyjęciem ze strony władz w Lagos. Dało ono podstawy do intensyfikacji stosunków bilateralnych,

${ }^{79}$ A. Olkiewicz, op. cit., s. 60-68.

${ }^{80}$ AMSZ, 1970 Dep. V sygn. 26/74 w. 1 Nigeria, Szyfrogram nr 1501 z Lagos, 10.02.1970, paginacja wielokrotna.

${ }^{81}$ AMSZ, 1970 Dep. V sygn. 26/74 w. 1 Nigeria, Szyfrogram nr 2144 z Lagos, 26.02.1970, paginacja wielokrotna. 
zawłaszcza w sferze gospodarczej, na czym zależało obu stronom. Zaufanie do Polski doprowadziło również do zaproszenia jej przedstawiciela do składu Międzynarodowej Grupy Obserwatorów badającej stan przestrzegania praw człowieka w rejonie konfliktu. Aktywność polskich członków grupy doprowadziła do wzrostu prestiżu państwa na arenie międzynarodowej, zwłaszcza wśród krajów rozwijających się.

Z perspektywy całokształtu stosunków politycznych i rywalizacji blokowej postawa państw socjalistycznych wobec konfliktu doprowadziła do wykrystalizowania się na nigeryjskiej scenie politycznej grup opowiadających się za ścisłą z nimi współpracą. Obok tradycyjnie przychylnych blokowi wschodniemu organizacji lewicowych były to grupy młodych oficerów o poglądach narodowych i antykolonialnych, sprzeciwiający się utrzymywaniu więzi, zwłaszcza gospodarczych, z byłą metropolią i innymi państwami Zachodu ${ }^{82}$.

Stanowisko polskiej dyplomacji wobec konfliktu w Biafrze w latach 1967-1970 należy uznać za dojrzałe i odpowiadające interesom państwa. Przemyślana polityka pozwoliła na ugruntowanie stosunków dwustronnych z ważnym partnerem afrykańskim oraz umocnienie wizerunku państwa jako podmiotu zaangażowanego $\mathrm{w}$ popieranie przestrzegania praw człowieka oraz pokojowych środków rozwiązywania sporów wewnętrznych i międzynarodowych. Jednocześnie należy podkreślić, iż była ona wpisana w szerszy kontekst wspólnej polityki państw socjalistycznych, w której Polska, odgrywając rolę państwa niezaangażowanego, uzyskała członkostwo w MGO reprezentując niejako cały blok wschodni.

\section{BIBLIOGRAFIA}

\section{Źródła archiwalne}

Archiwum Ministerstwa Spraw Zagranicznych

1965 Dep. V sygn. 55/70 w. 5 Nigeria; 1965 Dep. V sygn. 58/70 w. 2 Nigeria; 1966 Dep. V sygn. 56/70 w. 5 Nigeria; 1966 Dep. V sygn. 59/70 w. 2 Nigeria; 1967 Dep. V sygn. 57/70 w. 4 Nigeria; 1967 Dep. V sygn. 60/70 w. 2 Nigeria; 1968 Dep. V sygn. 31/66 w. 4 Nigeria; 1969 Dep. V sygn. 18/73 w. 2 Nigeria; 1969 Dep. V sygn. 19/73 w. 1; 1970 Dep. V sygn. 25/74 w. 2; 1970 Dep. V sygn. 26/74 w. 1 Nigeria.

${ }^{82}$ AMSZ, 1970 Dep. V sygn. 26/74 w. 1 Nigeria, Szyfrogram nr 8198 z Lagos, 24.08.1970, bp. 


\section{Opracowania}

Calvocoressi P., Polityka międzynarodowa po 1945 roku, Warszawa 2010.

Cielecki M., Stosunki polsko-nigeryjskie, [w:] Polacy w Nigerii, red. J. Machowski, Z. Łazowski, W. Kozak, Warszawa 1997, s. 44-52.

Knopek J., Stosunki polsko-zachodnioafrykańskie, Toruń 2013.

Kukułka J., Historia współczesnych stosunków międzynarodowych 1945-1994, Warszawa 1994.

Leśniewski M., Biafra 1966-1970, [w:] Konflikty kolonialne i postkolonialne w Afryce i Azji 1869-2006, red. P. Ostaszewski, Warszawa 2007, s. 446-455.

Machowski J., Po obu stronach frontu, [w:] Polacy w Nigerii, red. J. Machowski, Z. Łazowski, W. Kozak, Warszawa 1997, s. 68-77.

Milewski J., Polityka zagraniczna Nigerii 1960-1970, Warszawa 1972.

Muehlenbeck P., Czechoslovakia in Africa, 1945-1968, London 2016.

Olkiewicz A., Oficerowie polscy w Międzynarodowej Grupie Obserwatorów, [w:] Polacy w Nigerii, red. J. Machowski, Z. Łazowski, W. Kozak, Warszawa 1997, s. 60-68.

Sobczyński M., Zmiany granic w Afryce w okresie postkolonialnym, „Studia z Geografii Politycznej i Historycznej" 2015, t. 4, s. 65-93.

Srogosz T., Charakter prawny uti possidetis w prawie międzynarodowym, „Państwo i Prawo” 2011, nr 6, s. 64-76.

\section{Informatory}

Stosunki dyplomatyczne Polski 1944-1979 r. Informator, t. 5, opr. J. Patryas, Warszawa 1982.

\section{Reportaże}

Czekała-Mucha G., Bellona nad Zatoką Gwinejską, Warszawa 1981.

Kapuściński R., Anatomia zamachu stanu, [w:] R. Kapuściński, Heban, Warszawa 2008, s. 85-91.

Filip Urbański

\section{POLISH PEOPLE'S REPUBLIC TOWARDS THE CONFLICT IN BIAFRA 1967-1970}

$\mathrm{T}$ he article analyzes Poland's policy on the conflict in Biafra in 1967-1970. The basis for the research are unpublished materials collected in the Archive of the Ministry of Foreign Affairs. According to the author, the Polish diplomacy, maintaining a reserved position on the secession of the Eastern Province of Nigeria and supporting the federal government, was guided by the desire to maintain good political and economic relations. Sustainable politics allowed to take part in the International Observers Group, which contributed to the increase of the prestige of the state on the international arena.

Keywords: Biafra, Nigeria, Poland's foreign policy, Polish People's Republic, civil war. 